\title{
The On-Going Work of William Shakespeare
}

To the adaptations, permutations and reverberations of Shakespeare's works there is - apparently - no end.

- adaptations In our preview issue Hugh Howse described the recent publication by Oval Projects of London (in collaboration with the BBC) of cartoon versions of several Shakespeare tragedies, using the original folio texts and accompanied by stereo recordings. 'So what?' came an echo from New York: 'We did this years ago with Classic Comics Illustrated!' The two projects, we would argue, aren't at all similar, but both Oval and Classics Comics illustrate each in their own way how compellingly the Shakespeare canon lends itself to novel kinds of presentation.

- permutations Akira Kurosawa is a veteran Tokyo film-maker whose advice to apprentices of his craft is: 'In order to write scripts, you must first study the great novels and dramas of the world.' Following his own advice, Kurosawa went on to adapt first Macbeth (as his Throne of Blood) and now King Lear (as Ran, the Japanese for 'chaos'). The story is

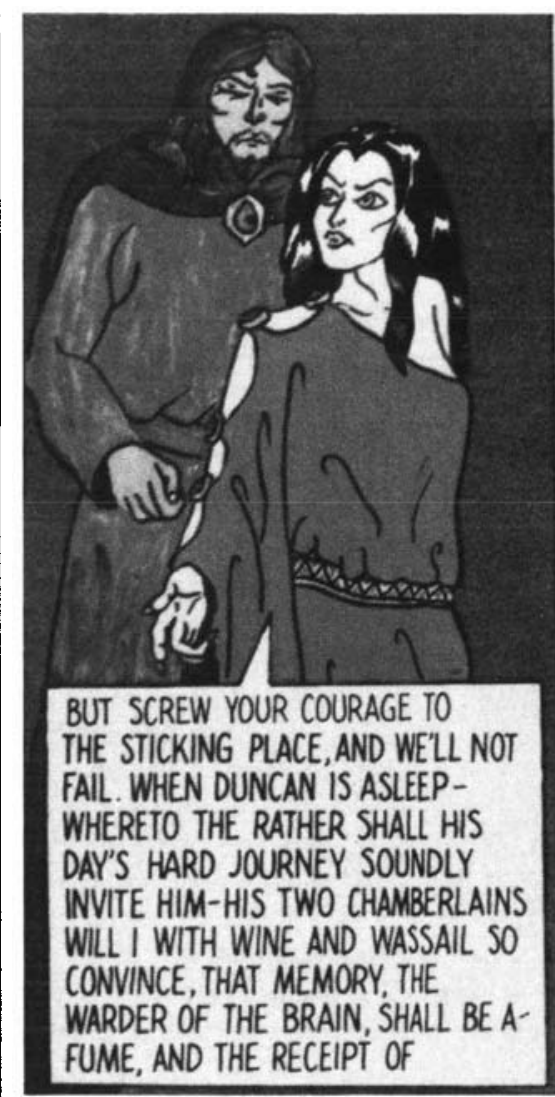

A frame from Oval Projects Macbeth, the original folio text of the play presented in cartoon form. re-set in 16th-century Japan, with Lear's daughters transmogrified into the sons of the Great Lord Hidetora, while Shakespeare's classic five-act structure has also been adapted - to the traditional three-part format of Noh drama.

- reverberations Five hundred years after the alleged crime, a British jury in 1984 found King Richard III not guilty of murdering his nephews in the Tower of London. The jury of twelve was assembled by London Weekend Television to deliver its verdict after four hours of televised testimony. LWT went to all this trouble and expense because Shakespeare had painted Richard as very guilty indeed. His Richard $I I I$ was an artful piece of Tudor propaganda; Henry VII, who deposed Richard, was grandfather to Queen Elizabeth, Shakespeare's sovereign at the time of writing and the last of the Tudor monarchs of England. Blackening Richard's name was politic then, but consciences in the literary community have grown steadily uneasier about it all with the passing of the years.

\section{Spanish in Miami Today}

The Cubanization of Miami and the Americanization of the Cubans who have settled in Miami are the subject of a report by Robert $M$. Press in the Christian Science Monitor of 24-30 November 84. Last year, the commissioners of Dade County, Florida, voted unanimously to make English the official language of the county, rather than endorse a policy of bilingualism. Dade County's population is about $40 \%$ Hispanic, while the city of Miami is close to $60 \%$ Hispanic, but it would appear that the commissioners' vote was a compromise of sorts between the hard facts and the fears of long-term Anglo residents.

The rules allow county documents relating to health, safety and tourism to be translated into, and published in, Spanish, while statistics indicate that the Cubans are assimilating, despite what some critics might have supposed: only 1 in 4 Cuban Americans speaks no English at all, while 2 in 4 speak it 'well to very well'. A local Cuban-born commentator told Press that he could not think of anyone in the second generation who is not fluent in English. At the same time, however, 9 out of every 10 Cuban Americans continue to speak Spanish in the home.

Miami is also the address of Spanish Today, a new magazine that deals with such issues as Hispanics in the United States, education, immigration, politics, foreign affairs and policy, new books, language usage and so forth. The editor is looking for young Hispanic teachers and writers to cover these subjects, and his call for material in TESOL Newletter 8/84 runs: 'Articles should be in English... Spanish Today will also consider for publication literary contributions written in Spanish.' [For further information, contact: Andres Rivero, Editor-in-Chief, Spanish Today, P.O. Box 909, Miami, Florida 33265, U.S.A.]

\section{Interesnaya}

In The Guardian on 24 November 84, Martin Walker reports from Moscow on a seriosnaya situatsia, well on the way to becoming a nationalnaya problema. It is the invasion of Russian by English and other foreign words. Pravda's letter columns have evidently been filled in recent months with complaints that the invaders are everywhere. Evidently, in addition to young high-life-isti spending their manny on trainer-style shoozy and the latest diski, the great motivatsia these days is to find the relevantnost in English-language scientific zhargon, so as to make your own dissertatsiya more interesnaya. 